\title{
Milk production in Saanen goats treated with repeated low doses of intermediate-release insulin during early lactation
}

\section{Erika Bezerra de Menezes ${ }^{1}$ iD Maria Gorete Flores Salles ${ }^{2}$ (iD Cleidson Manoel Gomes da Silva ${ }^{3}$ iD César Carneiro Linhares Fernandes ${ }^{4}$ (i) Giovanna Galeati ${ }^{5}$ (iD) Airton Alencar de Araújo ${ }^{4}$ (iD Davide Rondina ${ }^{4^{*}}$ (iD)}

${ }^{1}$ Departamento de Ciência Animal, Universidade Federal do Ceará (UFC), Fortaleza, CE, Brasil.

${ }^{2}$ Universidade da Integração Internacional da Lusofonia Afro-Brasileira (UNILAB), Redenção, CE, Brasil.

${ }^{3}$ Universidade Federal do Sul e Sudeste do Pará (UNIFESSPA), Xinguara, PA, Brasil.

${ }^{4}$ Faculdade de Veterinária, Universidade Estadual do Ceará (UECE), 60714-903, Fortaleza, CE, Brasil. E-mail: davide.rondina@uece.br. ${ }^{*}$ Corresponding author.

${ }^{5}$ Faculdade de Veterinária, Universidade de Bologna, Bologna, Itália.

ABSTRACT: The effect of insulin administration on the productive responses of Saanen goats during early lactation was investigated. Ten of 20 adult females were subjected to subcutaneous administration of intermediate-acting insulin (0.14UI/kg body weight) at 2, 9, and 14 days postpartum. Milk yield was measured twice daily for 13 weeks and milk samples were collected to measure protein and fat contents. Plasma levels of progesterone, insulin, non-esterifies fatty acids, glucose and other metabolites were measured. Results showed a significantly increased effect of insulin treatment on the content of milk fat and protein; moreover, milk production in the first and second postpartum weeks were higher than control group. The peak of lactation in the insulin group was achieved one week earlier in comparison to the control group. In addition, the milk production rate showed lower persistency (milk yield 13 week/milk yield at peak) in the same group. During the first four weeks of postpartum, treated animals showed greater weight loss and higher non-esterified fatty acid concentration, whereas no effect was observed on the concentration of progesterone and other metabolites. The above results indicated that repeated administration of insulin in dairy goats during early lactation increase yield and qualitative components of milk, but has substantial consequences on animal productive rate and metabolic response. Key words: goat, insulin, milk, postpartum, metabolites.

Produção de leite em cabras Saanen tratadas com repetidas doses baixas de insulina de liberação intermediária durante a lactação inicial

RESUMO: $O$ objetivo do estudo foi avaliar o efeito da administração de insulina sobre a resposta produtiva de cabras Saanen durante a lactação inicial. Dez de vinte fêmeas adultas foram sujeitas à administração subcutânea de repetidas e baixas doses de insulina de liberação intermediária aos 2, 9 e 14 dias pós-parto. A produção de leite foi mensurada duas vezes ao dia, por 13 semanas, e amostras de leite foram coletadas para mensurar teores de proteína e gordura. Os níveis plasmáticos de progesterona, insulina, ácidos graxos nãoesterificados (AGNE), glicose e outros metabólitos foram mensurados. Os resultados mostraram um efeito significativamente maior nos animais tratados com insulina sobre o teor de gordura e proteina no leite. Além disso, a produção de leite na primeira e segunda semana pós-parto foi maior no grupo tratado do que no grupo controle. O pico de lactação no grupo insulina foi alcançado uma semana antes em comparação ao grupo controle. Além disso, a taxa de produção de leite nos animais tratados mostrou uma menor persistência de produção de leite durante o periodo analisado. Durante as primeiras quatro semanas pós-parto, os animais tratados com insulina mostraram maior perda de peso e maior concentração de AGNE, enquanto não se observou nenhum efeito sobre a concentração de progesterona ou outros metabólitos. Os resultados acima indicam que repetidas doses de insulina em cabras leiteiras durante a lactação inicial aumenta o rendimento de produção e concentração de componentes qualitativos do leite, mas apresenta consequências consideráveis sobre taxa de produção animal e resposta metabólica.

Palavras-chave: cabra, insulina, leite, pós-parto, metabólitos.

\section{INTRODUCTION}

In goats, as well as other ruminants, the period between parturition and peak of lactation is characterized by prolonged negative energy balance (NEB) and represents a crucial point for the entire productive cycle of females (TOVAR-LUNA et al., 2010). This phase is the main responsible for affecting milk production, fertility, health of goat and kid and profitable farm productivity (JOUANY, 2006). Nutritive management plans usually used in this period aimed to maximize feed intake or increase diet energy density and ultimately improving the availability of glucogenic precursors in the rumen (HAYIRLI, 2006). Low insulin concentration in the plasma is associated with a negative energy balance during the early postpartum period; 
therefore, several studies have suggested that optimizing nutrient uptake altered concentrations of this metabolic hormone (MOLENTO et al., 2005). This approach appears to be consistent, particularly in many tropical areas, where the main drawback of dairy husbandry is sustaining alimentary intake at high temperatures and where the programs of high-energy diets to properly nourish the animals with high-quality feed are often competitive with human diet.

Insulinaemia is improved by the administration of a glucogenic feed additive such as propylene glycol or glycerol, the precursor of ruminal propionate, which is a commonly used therapy for energy deficit in dairy cows during postpartum (NIELSEN \& INGVARTSEN, 2004). However, when insulin is directly administered, the magnitude of an animal's response varies according to the dosage and time of release (HAYIRLI, 2006). An elevated dosage can induce severe feed intake and milk depression (MOLENTO et al., 2005). However, low doses can be usefully employed against lipidosis and ketosis in cows (HAYIRLI et al., 2002). In addition, it is hypothesized that both treatment intensities can influence milk quality. Based on this information, the aim of this study was to verify the effect of repeated administration of low doses of insulin during early lactation on the productive responses of Saanen goats raised in a tropical area of northeastern Brazil.

\section{MATERIALS AND METHODS}

The experiment was carried out at the farm "Lar Antônio de Pádua" (Pacatuba-CE, Brazil), located at $3^{\circ} 43^{\prime} \mathrm{S}$ and $38^{\circ} 30^{\prime} \mathrm{W}$, from August to March. The mean ambient temperature recorded during the experimental period was $26.9 \pm 0.78^{\circ} \mathrm{C}$ (mean \pm standard deviation [SD]). Forty-two multiparous Saanen adult cyclic female goats had their estrus synchronized using the buck effect and mated naturally with Saanen bucks from August to September. These animals were part of a herd of 150 does that were housed at ground level and grouped $(n=10)$ according to parity in boxes with free access to water and mineral salt, as well as to open paddock areas. Goats were fed twice per day (0600 and $1500)$ with a diet consisting of $70 \%$ elephant grass (Pennisetum purpureum) and 30\% leucaena leaves (Leucaena leucocephala) chopped in the trough ad libitum. A concentrate supplement $(29 \%$ soybean meal, $45 \%$ corn, $21.7 \%$ wheat bran, and $2 \%$ mineral, $1.3 \%$ lime, and $1 \%$ common salt) was provided at 1.6 $\mathrm{kg}$ per animal/day. At 45 days after mating, pregnancy was detected by ultrasonography, and 20 goats with twin fetuses were chosen with similar parity $2.4 \pm 0.7$ (mean $\pm \mathrm{SD}$ ) and kept in the flock. At parturition, all animals showed a similar body condition score (3.4 \pm 0.2 (mean $\pm \mathrm{SD})$, body weight $55.9 \pm 9.0 \mathrm{~kg}$ (mean $\pm \mathrm{SD}$ ) and milk production $(2.5 \pm 0.2 \mathrm{~kg} / \mathrm{doe}$, overall mean, $\mathrm{P}=0.12$ ). Kids were separated from their mothers 24 hours after parturition to permit them to suckle the first day colostrum. The kidding period was 58 days.

At 2, 9, and 14 days after parturition $(\mathrm{D}=0)$, the animals were divided into two groups: 10 goats were treated subcutaneously with $0.14 \mathrm{UI} / \mathrm{kg}$ body weight (BW)/day human intermediate-acting insulin, (100IU/ $\mathrm{mL}$; Humulin NPH, human insulin rDNA in isophane suspension, Eli Lilly Co., Fegersheim, France). The control group $(n=10)$ received an injection of saline solution as a placebo. Starting from parturition, the goats were weighed weekly and milk yield was measured twice daily (4:30AM, 1:30PM) from separation of the kids to the $13^{\text {th }}$ week postpartum. Milk samples were collected at $7,14,21$, and 28 days postpartum to determine protein and fat contents (AOAC, 1997).

Blood samples were collected in heparinized tubes by venipuncture before feeding and insulin administration beginning 50 days before parturition (weekly) and every 3 days for 28 days postpartum. Plasma samples were subsequently assayed for progesterone, insulin, non-esterified fatty acids (NEFA), glucose, urea, creatinine, gamma-glutamyl transferase (GGT), glutamyl pyruvic transaminase (GPT), and glutamyl oxaloacetic transaminase (GOT). Plasma glucose, urea, creatinine, GGT, GOT, and GPT were quantified by enzymatic assay (Wiener Laboratórios, Rosário, Argentina). Insulin and NEFA concentrations were measured using a commercial kit (NEFA: Medical Systems, Genova, Italy; Insulin: IBL International $\mathrm{GmbH}$, Flughafenstr, Hamburg, Germany) validated for goat (RONDINA et al., 2005). Plasma progesterone was analyzed using a radioimmunoassay as described previously (RONDINA et al., 2005).

Data was analyzed using the GLM procedures of the SAS program software (SAS Institute, Cary, NC, USA). Factors used in the model included group (control and insulin), time (interval of assessment considered), and interaction between group and time. To compare treatments, the $t$-test was used, while the differences between sampling intervals were analyzed using the paired $t$-test.

\section{RESULTS AND DISCUSSION}

Results obtained in the present study have shown that repeated low doses of intermediate release 
insulin administrated during early lactation have an effect on qualitative and quantitative milk production in dairy goats. Although, the total amount of milk produced was similar between groups (Table 1), lactation showed different patterns during thirteen weeks of post-partum (Figure 1). Milk yield was high in the treated group during the first and second week of lactation (Figure 1) and the peak of lactation in insulin goats was reached earlier (Table 1), approximately 10 days before the control group; however, no differences were observed concerning the extension of peak or the milk yield recorded in this period (Table 1). Milk yield decreased in both groups in the $4^{\text {th }}$ week of lactation, and continued to decrease in all animals until the $13^{\text {th }}$ week (Figure 1). In treated goats, lactation persistency was lower than that in the control group (Table 1). Thus, from weeks 7-13 of lactation in untreated animals, a higher milk production rate was observed (Figure 1).

Our results are consistent with those of HAYIRLI et al. (2002), who reported a significant increase in milk yield of lactating cows injected with a $0.14 \mathrm{UI} / \mathrm{BW}$ dose of slow-release insulin administrated on the $3^{\text {rd }}$ day postpartum. These authors suggesting that the effect of insulin on milk synthesis is indirect, and attributes to hypoglycemia the depression of milk yield related in other studies with cows also treated with exogenous insulin (KRONFELD et al., 1963; SCHMIDT, 1966). The hypoinsulinemia of early lactation is part of the changes that occur during the transition period in support of lactation. Low plasma insulin levels reduce glucose uptake by insulin-responsive adipose tissue and promote greater uptake of glucose by the mammary gland, which is not insulin-responsive (PATTON et al., 2004).

In this study, plasma insulin concentration did not show an overall significant effect of treatment or time (Table 1). However, in treated goats an increase of insulin level was observed between 1 and 4 days postpartum $(\mathrm{P}=0.01)$, and in $4^{\text {th }}$ day the insulin group showed a higher concentration than untreated animals $(10.3 \pm 1.2 \mu \mathrm{U} / \mathrm{mL}$ vs. $7.4 \pm 0.5 \mu \mathrm{U} / \mathrm{mL} ; \mathrm{P}=0.01)$.

Table 1 - Body weight (BW), weight loss, milk traits, and plasmatic metabolites levels in goats. Values are shown as the mean \pm standard error of the mean (SEM).

\begin{tabular}{|c|c|c|c|c|c|}
\hline \multirow[t]{2}{*}{ Attributes } & \multicolumn{2}{|c|}{-------------------------------Group------------------------ } & \multicolumn{3}{|c|}{------------------p - value-------------- } \\
\hline & Untreated & Insulin & Group & Time & GxT \\
\hline No. of does exposed & 10 & 10 & & & \\
\hline $\mathrm{BW}$ at parturition ${ }^{\mathrm{a}}, \mathrm{kg}$ & $54.1 \pm 3.0$ & $58.0 \pm 2.8$ & 0.35 & - & - \\
\hline Weight loss ${ }^{\mathrm{b}}, \mathrm{kg}$ & $5.0 \pm 0.6$ & $6.6 \pm 0.4$ & 0.04 & 0.01 & 0.99 \\
\hline \multicolumn{6}{|l|}{ Milk Traits } \\
\hline Peak of lactation, days & $20.1 \pm 3.5$ & $10.4 \pm 1.5$ & 0.02 & - & - \\
\hline Peak length ${ }^{\mathrm{c}}$, days & $18.0 \pm 3.4$ & $19.8 \pm 1.8$ & 0.65 & - & - \\
\hline Milk yield at peak, $\mathrm{kg}$ & $3.6 \pm 0.05$ & $3.5 \pm 0.04$ & 0.08 & - & - \\
\hline Total milk yield ${ }^{\mathrm{d}}, \mathrm{kg}$ & $230.8 \pm 19.4$ & $214.9 \pm 9.8$ & 0.47 & - & - \\
\hline Lactation Persistency $^{\mathrm{e}}, \%$ & $37.0 \pm 5.1$ & $22.5 \pm 2.6$ & 0.01 & - & - \\
\hline Milk fat, $\mathrm{g} / \mathrm{kg}$ & $31.2 \pm 1.2$ & $36.7 \pm 1.7$ & 0.01 & 0.01 & 0.01 \\
\hline Milk protein, $\mathrm{g} / \mathrm{kg}$ & $29.5 \pm 1.9$ & $35.0 \pm 1.7$ & 0.01 & 0.01 & 0.42 \\
\hline \multicolumn{6}{|l|}{ Metabolism $^{\mathrm{b}}$} \\
\hline Insulin, $\mu \mathrm{U} / \mathrm{mL}$ & $7.9 \pm 0.4$ & $8.2 \pm 0.4$ & 0.55 & 0.61 & 0.41 \\
\hline Glucose, mg/dL & $47.0 \pm 1.2$ & $51.4 \pm 1.0$ & 0.03 & 0.14 & 0.13 \\
\hline Urea, mg/dL & $46.4 \pm 0.8$ & $40.8 \pm 0.8$ & 0.01 & 0.02 & 0.23 \\
\hline Creatinine, $\mathrm{mg} / \mathrm{dL}$ & $0.68 \pm 0.02$ & $0.74 \pm 0.02$ & 0.05 & 0.27 & 0.48 \\
\hline \multicolumn{6}{|l|}{ Liver injury $^{b}$} \\
\hline GGT, U/L & $44.6 \pm 0.9$ & $45.9 \pm 1.1$ & 0.31 & 0.01 & 0.99 \\
\hline GOT, U/L & $79.8 \pm 2.1$ & $76.1 \pm 1.7$ & 0.16 & 0.47 & 0.67 \\
\hline GPT, U/L & $12.5 \pm 0.4$ & $10.8 \pm 0.4$ & 0.01 & 0.74 & 0.84 \\
\hline
\end{tabular}

aperformed after kidding; ${ }^{\mathrm{c}}$ number of days which milk yield remain at highest levels; ${ }^{\mathrm{d}}$ milk yield 13 weeks; ${ }^{\mathrm{e}} \mathrm{LP}=$ milk yield 13 week/ milk yield at peak; ${ }^{b}$ Mean and ANOVA results were referred to interval from 1 to 28 days of postpartum. GGT: gamma-glutamyl transferase, GPT: glutamyl pyruvic transaminase, GOT: glutamyl oxaloacetic transaminase. 
In addition, exogenous administration of insulin increased $(\mathrm{P}=0.03)$ the glucose concentration during the first 4 weeks postpartum (Table 1). Generally, exogenous insulin induces an increase in plasma glucose and plasma insulin; however, the magnitude of this response can vary according to the dosage as well as the type of insulin (rapid, intermediate and slow release) (HAYIRLI, 2006).

In relation to the specific pattern of lactation reported in the insulin group, BOVERA et al. (2004) and CANNAS et al. (1998) reported similar trend of milk production in dairy sheep fed with high availability of energy promoted by dietary non-structural carbohydrates. According to these authors one of the possible causes of the decrease in the persistence of lactation was that while at the beginning of lactation the greater availability of energy translates into milk production in intermediate lactation reduces or does not increase milk production but stimulates animal fattening (CANNAS et al., 1998).

Insulin treatment also improved fat and protein milk contents (Table 1). Both parameters showed an expected decrease in both groups during the first four weeks postpartum (Time effect: $\mathrm{P}<0.01$ ), but protein showed a different pattern in relation to fat milk. Therefore, a significant interaction between insulin treatment and time was observed only in fat levels. Milk fat content of insulin goats was higher than in the untreated animals at 7 and 14 days after parturition. By contrast, protein content decreased in goats treated with insulin slowly and values remained high with respect to the untreated group at 21 and 28 days postpartum.

Early lactating goats generally showed decreased milk protein or fat content because of the increase in milk volume until the peak of lactation (CHILLIARD et al., 2003). In this period, protein synthesis is very sensible to insulin and its action regulates protein metabolism in goats by clearly decreasing in vivo proteolysis (TESSERAUD et al., 2007). Enhancement of glucose availability increased milk protein by decreasing of amino acid requirements for gluconeogenesis, thus limiting the spared amino acids due to the increase of protein synthesis in the mammary gland (GRIINARI et al., 1997). A decreased rate of protein synthesis in muscle and skin tissue corresponds to a reduction in the use of amino acids in the extra mammary tissues, which makes amino acids available to the mammary gland (TESSERAUD et al., 2007).

It is well know that the onset of lactation is a vulnerable phase of the productive cycle. During this period, due of energetic cost of rising milk

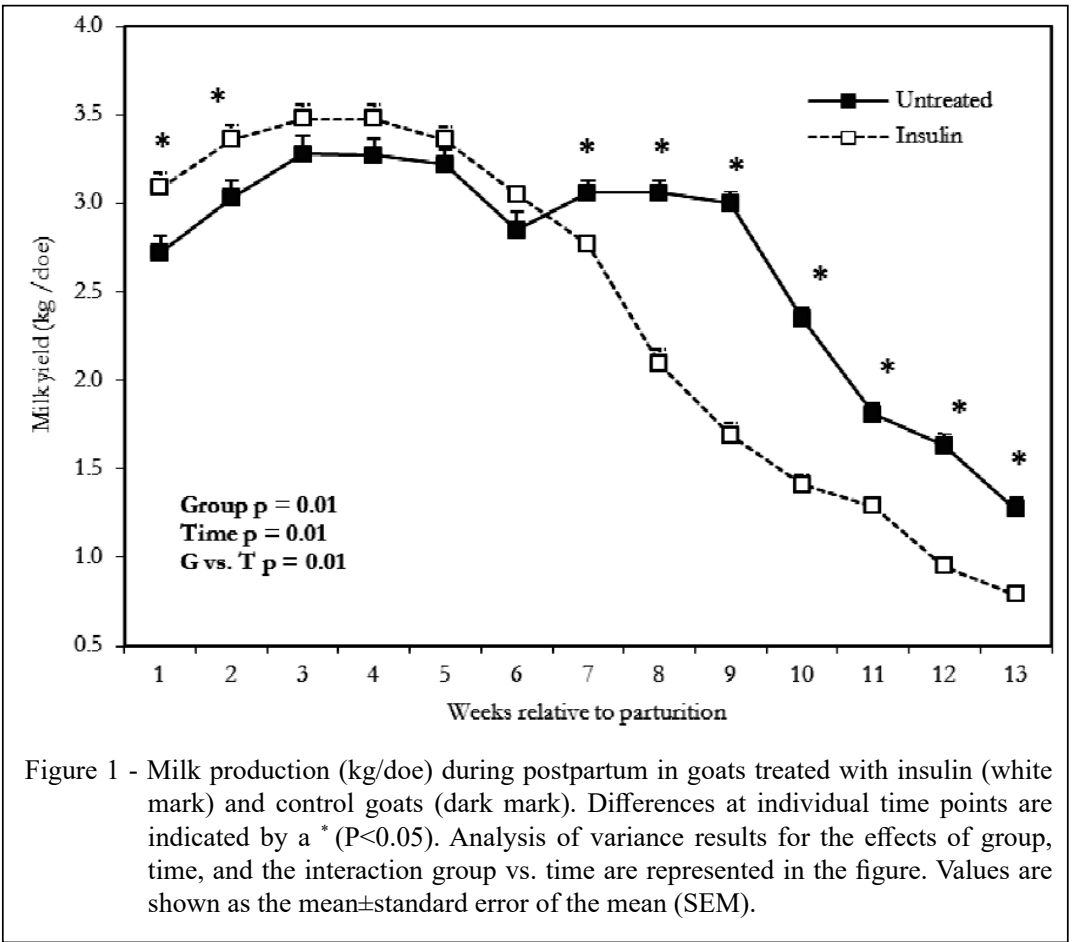

Ciência Rural, v.49, n.3, 2019. 
production, goats go through a high body tissue mobilization. A reduction in body mass is typical for lactating goats, which lose $5-10 \%$ of their initial body weight at parturition (SILVA et al., 2011). These findings are consistent with our data, which showed that mean weight loss over 4 weeks of lactation was $1.04 \pm 0.18$ and $1.19 \pm 0.20 \mathrm{~kg}$ for untreated and treated groups, respectively. However, weight loss occurred for an extensive period in treated goats and recovery of body weight began during the $4^{\text {th }}$ and $5^{\text {th }}$ weeks in the control and insulin groups, respectively. Therefore, the loss of body mass was higher $(\mathrm{P}=0.04)$ in insulin-treated animals (Table 1) and over the same time interval an increased concentration of NEFA was observed in the insulin group (Figure 2). In this experiment, insulin administration for 4 weeks postpartum increased the mean levels of NEFA compared to in untreated animals $(1.1 \pm 0.1 \mathrm{mM} / \mathrm{L}$ vs. $0.7 \pm 0.1 \mathrm{mM} / \mathrm{L}, \mathrm{P}<0.01)$.

Furthermore, plasma NEFA levels decreased slowly with insulin treatment compared to the control group (Figure 2). This increase in NEFA levels when associated with higher levels of milk fat during 4 weeks of lactation indicated that insulin treatment promoted greater mobilization of corporal reserves in lactating goats. This is not surprising and demonstrated the higher values of milk traits in the earlier weeks of postpartum. According to DUNSHEA et al. (1988), the increased NEFA mobilization during the negative energy balance in goats is due to a decrease in the reesterification of fatty acids associated with increased lipolysis. When energy balance is negative, animals mobilize lipids stored in adipose tissues, mainly in the form of NEFA. CHILLIARD et al. (2003) reported that in early lactation energy balance, plasma NEFA and milk fat content are highly correlated in goats. Concentration of liver triglyceride is negatively correlated with plasma glucose and serum insulin concentrations and positively correlated with plasma NEFA (McNAMARA, 1991).

NEFA is correlated negatively with energy balance in early lactating and can; therefore, be used as an indicator of energy balance and metabolic disorder (MULLIGAN, 2006). However, our results were not shown to promote an excessive quantity of nonesterified fatty acids in goats. During the experimental period, the highest value was $1.3 \pm 0.9 \mathrm{mM} / \mathrm{L}$ of NEFA in insulin group, which agrees of what was reported

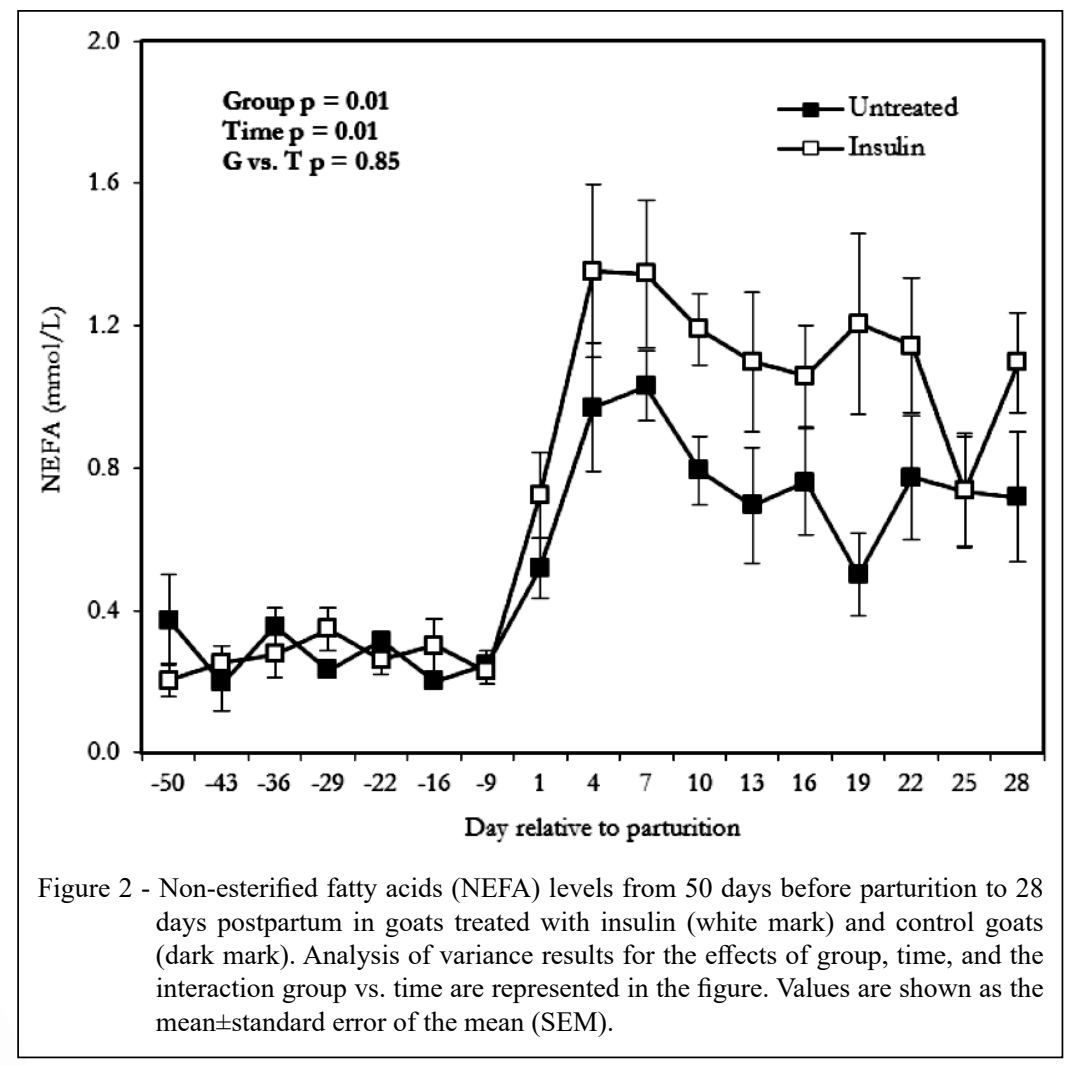

Ciência Rural, v.49, n.3, 2019. 
for dairy goats in early lactation (DUNSHEA et al. 1988). Furthermore, the regular hepatic and renal activity verified for metabolites strongly suggested the non-appearance of subclinical metabolic disorders in goats treated with insulin.

All levels of the metabolites (Table 1) are in agreement with previously published studies stipulated for goats and suggested the non-appearance of subclinical metabolic disorders in goats. No significant changes in liver (gamma-glutamyl transferase-GGT, and glutamic oxaloacetic transaminase-GOT) and kidney function metabolites (creatinine) were observed during the experimental period. For urea and glutamyl pyruvic transaminase-GPT, control does showed mean values higher than the insulin group (Table 1).

Insulin treatment did not affect the progesterone pattern after parturition. Both groups showed no indication of a corpora lutea during this period, and in fact in all animals, progesterone plasma concentrations were $<1 \mathrm{ng} / \mathrm{mL}$. Typically, the onset of lactation is a vulnerable phase of the reproductive cycle. In goats, the restart of luteal activity depends on the extent of the negative energy balance, which in turn depends on the capacity of the animal to fully recover from the loss of stored body reserves, which did not occur during period investigated. As well recognized the negative balance during early lactation reduced levels of progesterone that influence uterine function, delays timing of first ovulation and exerts consequences on early embryo development and fertility during the breeding period (INSKEEP, 2004).

\section{CONCLUSION}

In conclusion, we reported that low doses of insulin in dairy goats could be used successfully during early lactation to enhance milk yield and the quality of milk components. However, the low persistency of lactation and increase in NEFA plasma levels demonstrated that increased productivity was associated with significant metabolic efforts. Therefore, we do not recommend the use of the proposed method.

\section{BIOETHICS AND BIOSSECURITY COMMITTEE APPROVAL}

All procedures used in this study were approved by the Ethics Committee in Animal Experimentation of the Universidade Estadual do Ceará (UECE) ( $\mathrm{n}^{\circ}$ 09656828-3/09).

\section{ACKNOWLEDGEMENTS}

This work was supported by Proex grant No. 23038.002808/2017-56. Menezes B. E. was the recipient of a scholarship from $\mathrm{CNPq} / \mathrm{Brazil}$. Rondina $\mathrm{D}$. is senior investigator of $\mathrm{CNPq} / \mathrm{Brazil}$.

\section{DECLARATION OF CONFLICT OF INTERESTS}

The authors declare no conflict of interest. The founding sponsors had no role in the design of the study; in the collection, analyses, or interpretation of data; in the writing of the manuscript, and in the decision to publish the results.

\section{AUTHORS' CONTRIBUTIONS}

Davide Rondina and Erika Bezerra de Menezes conceived and designed experiments. Erika Bezerra de Menezes and Maria Gorete Flores Salles performed the experiments, Erika Bezerra de Menezes and Giovanna Galeati carried out the lab analyses. Maria Gorete Flores Salles and Airton Alencar de Araújo supervised and coordinated the animal experiments and provided clinical data. Davide Rondina performed statistical analyses of experimental data. Davide Rondina, Erika Bezerra de Menezes, César Carneiro Linhares Fernandes and Cleidson Manoel Gomes da Silva, prepared the draft of the manuscript. All authors critically revised the manuscript and approved of the final version.

\section{REFERENCES}

AOAC. Association of Official Analytical Chemists. Official Methods of Analysis. AOAC Intl. Gaithersburg, MD, 1997. 16th ed.

BOVERA, F. et al. Effect of non-structural carbohydrate dietary content on the productive performance of Sarda primiparous ewes. Italian Journal of Animal Science, v.3, p.61-70, 2004. Available from: <http://dx.doi.org/10.4081/ijas.2004.61>. Accessed: Mar. 02, 2019. doi: 10.4081/ijas.2004.61.

CANNAS, A. et al. Effect of the dietary energy and protein concentration on the concentration of milk urea nitrogen in dairy ewes. Journal of Dairy Science, v. 81:499-508, 1998. Available from: $<$ http://dx.doi.org/10.3168/jds.S0022-0302(98)75602-4>. Accessed: Mar. 02, 2019. doi: 10.3168/jds.S0022-0302(98)75602-4.

CHILLIARD, Y. et al. A Review of nutritional and physiological factors affecting goat mMilk Lipid synthesis and lipolysis. Journal of Dairy Science, v.86, p.1751-1770, 2003. Available from: $<$ https://doi.org/10.3168/jds.S0022-0302(03)73761-8>. Accessed: Mar. 02, 2019. doi: 10.3168/jds.S0022-0302(03)73761-8.

DUNSHEA, F. R. et al. Relations between plasma non-esterified fatty acid metabolism and body tissue mobilization during chronic undernutrition in goats. British Journal of Nutrition, v.60, p.633-644, 1988. Available from: <https://doi.org/10.1079/ BJN19880133>. Accessed: Mar. 02, 2019. doi: 10.1079/ BJN19880133.

GRIINARI, J. M., et al. Role of insulin in the regulation of milk fat synthesis in dairy cows. J. Dairy Sci. v.80, 1076-1084, 1997. Available from: <https://doi.org/10.3168/jds.S0022-0302(97)76032-6>. Accessed: Mar. 02, 2019. doi: 10.3168/jds.S0022-0302(97)76032-6.

HAYIRLI, A. The Role of exogenous insulin in the complex of hepaticlLipidosis and ketosis associated with insulin resistance phenomenon in postpartum dairy cattle. Veterinary Research Communications, v.30, p.749-774, 2006. Available from: $<$ https:// 
doi.org/10.1007/s11259-006-3320-6>. Accessed: Mar. 02, 2019. doi: $10.1007 / \mathrm{s} 11259-006-3320-6$.

HAYIRLI, A. et al. Effects of slow-release insulin on production, liver triglyceride and metabolic profiles of Holsteins in early lactation. Journal of Dairy Science, v.85, p.2180-2191, 2002. Available from $<$ https://doi.org/10.3168/jds.S0022-0302(02)74297-5>. Accessed: Mar. 02, 2019. doi: 10.3168/jds.S0022-0302(02)74297-5

JOUANY, J. P. Optimizing rumen functions in the close-up transition period and early lactation to drive dry matter intake and energy balance in cows. Anim. Rep. Sci. v.96, 250-264, 2006. Available from: $<$ https://doi.org/10.1016/j.anireprosci.2006.08.005>. Accessed: Mar. 02, 2019. doi: 10.1016/j.anireprosci.2006.08.005

KRONFELD, D.S. et al. Depression of milk secretion during insulin administration. Journal of Dairy Science, v.46, p.559563, 1963. Available from: <https://doi.org/10.3168/jds.S00220302(63)89095-5>. Accessed: Mar. 02, 2019. doi: 10.3168/jds. S0022-0302(63)89095-5.

McNAMARA, J.P. Regulation of adipose tissue metabolism in support of lactation. Journal of Dairy Science, v.74, p.747-719, 1991. Available from: $<$ https://doi.org/10.3168/jds.S0022-0302(91)78217-9> Accessed: Mar. 02, 2019. doi: 10.3168/jds.S0022-0302(91)78217-9.

MOLENTO, C.F.M. et al. Effects of insulin, recombinant bovine somatotropin and their interaction on DMI and milk fat production in dairy cows. Livestock Production Science, v.97, p.173-182, 2005. Available from: <https://doi.org/10.1016/j. livprodsci.2005.04.004>. Accessed: Mar. 02, 2019. doi: 10.1016/j. livprodsci.2005.04.004.

NIELSEN, N.; INGVARTSEN, K. Propylene glycol for dairy cows. A review of the metabolism of propylene glycol and its effects on physiological parameters, feed intake, milk production and risk of ketosis. Animal Feed Science and Technology, v.115, p.191-213, 2004. Available from: <https://doi.org/10.1016/j. anifeedsci.2004.03.008>. Accessed: Mar. 02, 2019. doi: 10.1016/j. anifeedsci.2004.03.008.

PATTON, R.S. et al. Effects of dietary glucogenic precursors and fat on feed intake and carbohydrate status of transition dairy cows. Journal of Dairy Science, v.87, p.2122-2129, 2004. Available from: $<$ https://doi. org/10.3168/jds.S0022-0302(04)70031-4>. Accessed: Mar. 02, 2019. doi: $10.3168 /$ jds.S0022-0302(04)70031-4.

RONDINA, D. et al. Effect of nutrition on plasma progesterone levels, metabolic pParameters and small follicles development in unstimulated goats reared under constant photoperiod Regimen. Reproduction in Domestic Animals, v.40, p.548-552, 2005. Available from: $<$ https:// doi.org/10.1111/j.1439-0531.2005.00631.x>. Accessed: Mar. 02, 2019. doi: 10.1111/j.1439-0531.2005.00631.x.

SCHMIDT, G.H. Effect of insulin on yield and composition of milk of dairy cows. Journal of Dairy Science, v.49, p.381-385, 1966 Available from: $<$ https://doi.org/10.3168/jds.S0022-0302(66)87878-5>. Accessed: Mar. 02, 2019. doi: 10.3168/jds.S0022-0302(66)87878-5.

SILVA, L.M. et al. Reproductive responses and progesterone levels of post-partum oestrus synchronization in goats with different body reserves. Italian Journal of Animal Science, v. 10, p.220-224, 2011. Available from: <https://doi.org/10.4081/ijas.2011.e42>. Accessed: Mar. 02, 2019. doi: 10.4081/ijas.2011.e42.

TESSERAUD, S., et al. Regulation of protein metabolism by insulin: value of different approaches and animal models. Domestic Animal Endocrinology, 33, 123-142, 2007. Available from: <https://doi. org/10.1016/j.domaniend.2006.06.002>. Accessed: Mar. 02, 2019. doi: 10.1016/j.domaniend.2006.06.002.

TOVAR-LUNA, I., et al. Effects of stage of lactation and dietary concentrate level on energy utilization by Alpine dairy goats. Journal of Dairy Science, 93, 4818-4828, 2010. Available from: $<$ https://doi.org/10.3168/jds.2010-3315>. Accessed: Mar. 02, 2019. doi: $10.3168 /$ jds.2010-3315. 